\title{
Komunikasi Politik Anggota Legislatif Perempuan Di Kota Majalengka
}

\author{
Political Communication Of Female Legislators In MajalengKa City
}

Nurannafi FSM

(Dosen ilmu komunikasi, universitas DR. Soetomo)

syammaella@gmail.com

\begin{abstract}
Political communication is considered as a process of conveying political messages from the political elite to the community. In return, the conveyed political message obtains the expected response such as the process of political decisionmaking in a democratic, transparent, and accountable. Political communication of women legislators in the policy has distinctive characteristics for each member. This is due to the cultural factors and party policy systems that are very influential on the carrier of women legislators. This study aims to determine the political communication of female legislators in the budget preparation policy of Community Empowerment, Women and Family Planning Board in Assembly at Majalengka Regency. The unit of analysis carried out in this research includes the communication of undertaken process related to communicators, the contents of messages that were conveyed, the media used, the communication objectives, as well as the preparation and formulation of strategies in the budgeting policy of the Community Empowerment, Women and Family Planning Board conducted by legislators of Majalengka Regency.
\end{abstract}

Keywords: communication, politics, community empowerment, women, children

\begin{abstract}
Abstrak. Komunikasi politik sebagai proses penyampaian pesan politik dari elite politik kepada masyarakat secara timbal balik agar pesan politik yang disampaikan memperoleh respons yang diharapkan seperti terjadinya proses pengambilan keputusan politik secara demokratis, transparan, dan tanggung gugat (akuntabilitas). Komunikasi politik anggota legislatif perempuan dalam kebijakan memiliki ciri khas yang berbeda pada setiap anggota, hal ini dikarenakan faktor budaya dan sistem kebijakan partai yang sangat berpengaruh pada perjalanan para legislatif perempuan. Penelitian ini bertujuan untuk mengetahui komunikasi politik anggota legislatif perempuan dalam kebijakan penyusunan anggaran Badan Pemberdayaan Masyarakat, Perempuan dan KB di DPRD Kabupaten Majalengka. Unit analisis yang dilakukan pada penelitian ini meliputi proses komunikasi yang dilakukan berkaitan dengan komunikator, isi pesan yang akan disampaikan, media yang digunakan, sasaran komunikasi, serta persiapan dan perumusan strategi dalam kebijakan penyusunan anggaran Badan Pemberdayaan Masyarakat, Perempuan dan KB yang dilakukan oleh anggota legis latif Kabupaten Majalengka.
\end{abstract}

Kata kunci: komunikasi, politik, pemberdayaan masyarakat, perempuan, anak

\section{Pendahuluan}

Komunikasi politik anggota legislatif perempuan dalam hal kebijakan penyusunan anggaran dimulai dari pembahasan Rencana Kerja
Anggaran (RKA) yang diajukan oleh pihak eksekutif kepada legislatif sampai pada pembuatan kebijakan mengenai anggaran dari beberapa program yang sudah dibahas pada setiap komisi. Komunikasi politik yang dilakukan 
anggota legislatif perempuan pada komisi D, lebih memperhatikan pada beberapa aspek yang dianggap mampu mendukung berhasilnya program serta anggaran yang akan ditetapkan. Beberapa aspek yang dapat dipersiapkan oleh anggota legislatif perempuan diantaranya, anggota legislatif perempuan harus mengumpulkan informasi-informasi dari masyarakat mengenai pembangunan sebelumnya, serta harapan masyarakat mengenai pembangunan yang akan datang. Selain itu, cukup intens dalam melakukan rapat fraksi, yang membahas mengenai keterlibatan anggota legislatif perempuan dalam kebijakan penyusunan anggaran baik di dalam komisi maupun yang terlibat pada badan anggaran.

Komunikasi politik anggota legislatif perempuan secara sederhana dapat didefinisikan sebagai proses komunikasi dalam kebijakan penyusunan anggaran Badan Pemberdayaan Masyarakat, Perempuan dan Keluarga Berencana yang berdampak politik mengacu pada kontek pesan-pesan politik, yang disampaikan secara formal maupun informal. Komunikasi politik ini akan berkaitan dengan komunikator politik, yaitu bagaimana anggota legislatif perempuan menyampaikan pesan yang disampaikanya pada rapat komisi D mengenai pembahasan Rencana Kerja Anggaran (RKA), pada rapat RAPBN dan terakhir pada rapat APBN (rapat badan anggaran). Komunikator berkaitan dengan kredibilitas yang dimiliki oleh setiap anggota legislatif perempuan. Kredibilitas selalu berubah tergantung pada persepsi publik, topik yang dibahas dan situasi. Kredibilitas anggota legislatif perempuan berkaitan dengan keahlian dan kepercayaan yang dimilikinya. Tidak hanya itu, komunikasi politik juga pada pembahasan ini mencakup isi pesan yang disampaikan dalam menyuarakan program yang memfasilitasi perempuan dalam Rencana Kerja Anggaran (RKA) Badan Pemberdayaan Masyarakat, Perempuan dan KB pada rapat komisi D. Selain itu penggunaan media serta segmentasi khalayakpun merupakan bagian darikomunikasi politik anggota legislatif perempuan.

Komunikasi politik sebagai proses penyampaian pesan politik dari elite politik kepada masyarakat secara timbal balik agar pesan politik yang disampaikan memperoleh respons yang diharapkan seperti terjadinya proses pengambilan keputusan politik secara demokratis, transparan, dan tanggung gugat (akuntabilitas). Komunikasi politik anggota legislatif perempuan dalam kebijakan memiliki ciri khas yang berbeda pada setiap anggota, hal ini dikarenakan faktor budaya dan sistem kebijakan partai yang sangat berpengaruh pada perjalanan para legislatif perempuan.

Para pakar ilmu komunikasi lebih menjelaskan bahwa pembendaharaan kata para komunikator politik berisi istilah- istilah yang samarsamar, seperti: demokrasi, kemerdekaan, dan keadilan, yang maknanya diperselisihkan. (Nimmo, 2005:101)

Penggunaan pembicaraan dalam politik dalam beberapa segi, yaitu meyakinkan dan membangkitkan, otoritas sosial, ungkapan personal, dan diskusi publik. Melalui kata-kata politik dan permainan kata, para aktor politik atau komunikator politik menciptakan citra tentang objek dan tentang kondisi di dalam dunia konflik dan kerja sama sosial manusia

Setiap program kerja serta anggaran yang dibahas pada komisi D mengacu pada kebutuhan masyarakat dengan tujuan meningkatkan kesejahteraan masyarakat. Pada setiap 
proses kebijakan penyusunan tersebut, maka setiap anggota legislatif membawa visi misi pribadi maupun partai yang mendukungnya. Keberadaan partai politik sangat mempengaruhi terhadap perilaku anggota legislatif di parlemen.

Partai politik merupakan suatu kelompok yang terorganisasi, yang anggota- anggotanya memiliki orientasi nilai-nilai yang sama untuk memperoleh kekuasaan politik dan merebut kedudukan politik agar dapat melaksanakan programnya. Biasanya kekuasaan politik dan kedudukan politik itu diperoleh melalui cara konstitusional untuk mempengaruhi dan melaksanakan kebijakan umum. (Budiardjo, 2010: 104)

Namun dukungan serta program dari partai yang menjadi identitas anggota legislatif terkadang lebih kuat untuk mengantarkan anggota legislatif perempuan dalam merealisasikan program-program yang pro perempuan. Keberadaan partai politik seharusya menjadi instrumen yang kuat untuk memberikan daya dorong terhadap artikulasi politik perempuan. Mereka tidak lagi dipandang sebagai aksesoris politikberjuang membesarkan partai. Tentu saja hal ini memerlukan kesadaran yang tinggi dari kalangan partai politik, terutama elite-elitnya yang biasanya cenderung tidak ingin berbagai kekuasaan dengan orang lain.

Pada kondisi inilah, keberadaan partai politik sangat mendominasi pergerakan komunikasi politik anggota legislatif, maka politik anggaran mulai dilakukan oleh beberapa anggota legislatif pada rapat komisi D pembahasan Rencana Kerja Anggaran (RKA). Politik anggaran yang pro rakyat ataukah politik anggaran yang pro kepentingan parlemen atau lembaga yang terkait. Program-program yang pro rakyat yang diperjuangkan oleh anggota legislatif perempuan adalah lebih memperhatikan dan memberikan solusi terhadap program yang berpihak kepada pemberdayaan perempuan yang membicarakan sejumlah besar perempuan, seperti contoh perempuan yang menjadi korban pencemaran di daerah industri, TKW, perempuan yang tidak mendapatkan pelayanan kesehatan dan gizi yang cukup, yang jerih payahnya bekerja di sektor domestik tidak dihargai, perempuan yang mengalami kekerasan rumah tangga dan beban ganda, perempuan miskin, perempuan yang diperdagangkan, yang dipaksa melacur karena miskin, dll.

Tetaplah segala perilaku dalam komunikasi politiknya harus mengacu kepada Pembentukan Rencana Pembangunan Jangka Menengah (RPJM) Daerah yang merupakan tuntutan dalam melaksanakan pembangunan lima tahun ke depan guna memenuhi kebutuhan masyarakat yang dinamis sesuai dengan aspirasi yang berkembang melalui mekanisme yang berlaku untuk mewujudkan tata pemerintahan yang baik. Perubahan ini menjadi salah satu resolusi dimana pemberdayaan perempuan mulai ditingkatkan diberbagai sektor kehidupan, sehingga Badan Pemberdayaan Masyarakat, Perempuan dan Keluarga Berencana inilah menjadi wadah yang akan memfasilitasi hal tersebut. Tentunya hal ini harus didukung oleh para pembuat kebijakan yang harus lebih berpihak kepada programyang pro- gender. Didukung dengan adanya affirmative action (kuota kursi perempuan di DPR sebanyak 30\%) bagi perempuan untuk menjadi anggota legislatif. Diharapkan keberadaan anggota legislatif perempuan sebagai para pembuat kebijakan lebih terfokus dalam persoalan perempuan.

Pada pemilu legislatif 2009 memberikan kesempatan kepada kaum 
perempuan untuk berjuang dan menjadi pelaku politik secara aktif. Setiap parpol memiliki calon anggota legislatif perempuan yang dikirim ke DPRD, DPD, Tahun 2009 pada pasal 8 ayat 1 dan Undang-Undang No. 2 Tahun 2008 tentang Partai Politik, dalam pasal 20 ditegaskan bahwa kepengurusan partai politik tingkat pusat, Provinsi dan Kabupaten/Kota disusun dengan memperhatikan keterwakilan perempuan paling rendah $30 \%$ yang diatur dalam Anggaran Dasar dan Anggaran Rumah Tangga partai politik masing-masing. (Wasistiono,2009:55).

Peranan anggota legislatif perempuan yang terlibat dalam pembuatan kebijakan legislatif diharapkan membuat fenomena komunikasi politik indonesia mengalami perubahan yang cepat. Pemberian kesempatan bagi perempuan untuk dapat berkiprah dikancah politik memberikan nuansa komunikasi politik yang berbeda. Dengan programprogram kerja dari Badan Pemberdayaan Masyarakat, Perempuan dan Keluarga Berencana yang tentunya lebih berpihak pada kesejahteraan Ibu dan anak, diharapkan mampu diperjuangkan kebijakannya di ranah legislatif.

Peranan perempuan pada bidang politik acapkali dilekatkan dengan sisi feminimitas dan atribusi pada label label domestiknya (Susilo, 2016). Pada akhirnya politisi perempuan dikaitkan dengan sosoknya sebagai ibu.

Karena itu pada penelitian ini peneliti lebih menintikberatkan dalam membahas kebijakan penyusunan anggaran pada program-program Badan Pemberdayaan Masyarakat, Perempuan dan Keluarga Berencana, yang tentunya ini hanya bisa diperjuangkan dan lebih diperhatikan oleh anggota legislatif perempuan. Kondisi dalam berbagai bidang sosial yang masih berbasis gender menjadikan perempuan dan laki- laki memasuki ruang publik dari lokasi sosial yang berbeda, dan hal ini menentukan legitimasi mereka dalam proses politik. Laki-laki sering memaknai politik hanya untuk memenuhi hal-hal yang kolosal, pembangunan infrastruktur, pertahanan negara, perluasan ekspansi dan eksploitasi ekonomi dan larut dalam pertengkaran serta persaingan politik, sehingga melupakan hal-hal yang bersifat kesejahteraan dan kemanusiaan. Dengan jumlah keterwakilan yang memadai di lembaga eksekutif dan legislatif, diharapkan perempuan mampu memberi perhatian lebih pada permasalahan perempuan yang kerap dilupakan laki- laki. Kuota 30 persen merupakan peluang cukup besar bagi wanita Indonesia berada di publik, dan dapat terlibat secara langsung dalam pengambilan keputusan.

Peluang ini sebagai tantangan bagi perempuan Indonesia. Keterwakilan perempuan yang sudah didengungkan dan sudah menjadi suatu keputusan yang di muat dalam UU.No.12 tahun 2003 denganAdanya anggota legislatif perempuan, diharapkan program-program yang berkaitan dengan perempuan dapat di realisasikan dengan cepat, walaupun masih kurang diperhatikan, namun tetap harus diperjuangkan oleh para anggota legislatif perempuan.

Mendorong peningkatan keterwakilan perempuan memang harus dilakukan secara komprehensif dari hulu ke hilir. Mulai dari tahap pembentukn Badan Pemberdayaan Masyarakat, Perempuan, dan Keluarga Berencana, pemberian kesempatan bagi perempuan diranah legislatif untuk membuat kebijakan, serta perlahanlahan dapat membangun kesadaran perempuan untuk ingin terjun ke dunia politik, tahap memperkuat kapasitas perempuan untuk mampu bersaing dalam pemilu hingga tahap melakukan 
advokasi agar Revisi UU Paket Politik (UU Penyelenggara Pemilu, UU Pemilu, UU Partai Politik, UU Susunan Kedudukan) dapat memberikan jaminan keterwakilan minimal 30\%. Keterwakilan perempuan antar periode diharapkan bisa bersinergi, sehingga apa yang telah dilakukan tidak terputus. Begitupun Kabupaten Majalengka, yang terdiri dari enam orang anggota legislatif perempuan, perannya diharapkan mampu mewarnai kebijakan penyusunan anggaran yang tentunya lebih ke pro gender. Setiap tahun dalam 5 tahun jabatannya selalu memberikan perubahan-perubahan terhadap kebijakan-kabijakan yang mudah direalisasikan oleh anggota legislatif perempuan.

Berdasarkan pemahaman itu pula maka focus permasalahan yang hendak ditelaah dalam penelitian ini adalah "Bagaimanakah Komunikasi Politik anggota legislatif perempuan dalam kebijakan penyusunan anggaran Badan Pemberdayaan Masyarakat, Perempuan dan KB di DPRD Kabupaten Majalengka?"

Berdasarkan focus penelitian tersebut, dapat diketahui bahwa penelitian ini bertujuan untuk mengetahui komunikasi politik anggota legislatif perempuan dalam kebijakan penyusunan anggaran Badan Pemberdayaan Masyarakat, Perempuan dan KB di DPRD Kabupaten Majalengka. Sudah barang tentu, meneliti proses komunikasi yang dilakukan berkaitan dengan komunikator, isi pesan yang akan disampaikan, media yang digunakan, sasaran komunikasi, serta persiapan dan perumusan strategi dalam kebijakan penyusunan anggaran Badan Pemberdayaan Masyarakat, Perempuan dan KB yang dilakukan oleh anggota legislatif Kabupaten Majalengka

\section{Kajian Teoritik}

1. Komunikasi Politik Istilah komunikasi politik lahir dari dua istilah yaitu "komunikasi" dan "politik". Hubungan kedua istilah itu dinilai besifat intim dan istimewa karena pada domain politik, proses komunikasi menempati fungsi yang fundamental. Bagaimanapun pendekatan komunikasi telah membantu memberikan pandangan yang mendalam dan lebih halus mengenai perilaku politik (Nasution,1990: 9).

Studi tentang komunikasi politik pada umumnya berkisar di seputar, bagaimana peranan komunikasi di dalam fungsi politik. Komunikasi politik mempersembahkan semua kegiatan sistem politik, baik masa kini maupun masa lampau sehingga aspirasi dan kepentingan dikonversikan menjadi berbagai kebijaksanaan. Pemikiran tersebut berangkat dari pemikiran bahwa komunikasi adalah suatu proses yang menyatu dengan gejala politik (Panuju, 1997:40).

Tidak dapat dipungkiri bahwa bila mengupas komunikasi politik, maka kita harus menyinggung pula tentang komunikasi, karena komunikasi politik merupakan bagian daripadanya. Karena itu, pada komunikasi politik anggota legislatif perempuan diawali oleh komunikasi yang dilakukannya. Kata "politik" seperti halnya komunikasi, maka politik adalah proses; dan seperti komunikasi juga politik melibatkan pembicaraan. Ini

bukan pembicaraan dalam arti sempit seperti kata yang diucapkan, melainkan pembicaraan dalam arti yang lebih inklusif, yang berarti segala cara orang bertukar simbol, kata-kata yang dituliskan dan diucapkan, gambar, gerakan, sikap tubuh, perangai dan pakaian. Karena itu, politik adalah pembicaraan, atau lebih tepat, kegiatan 
politik adalah berbicara. (Nimmo,2005:8)

Politik sebagai suatu proses dimana dalam perkembangan proses tersebut seseorang menerima orientasi politik dan pola tingkah laku tertentu. Komunikasi politik menyalurkan aspirasi dan kepentingan politik rakyat yang menjadi input sistem politik dan pada waktu yang bersamaan komunikasi politik juga menyalurkan kebijakan yang diambil atau output dari sistem politik. Dengan demikian melalui komunikasi politik maka rakyat dapat memberikan dukungan, menyampaikan aspirasi dan melakukan pengawasan terhadap sistem politik. Melalui itu pula rakyat akan mengetahui apakah dukungan, aspirasi, dan pengawasan itu tersalurkan atau tidak sebagaimana dapat mereka simpulkan dari kebijakan politik yang diambil. Hakikat komunikasi politik adalah upaya untuk mewujudkan tujuan pemikiran politik yang melibatkan berbagai pihak sebagaimana mereka harapkan.Namun demikian diantara beberapa definisi yang disebutkan, Brian Mc Nair memberikan penekanan bahwa definisi komunikasi politik mencakup retorika politik baik verbal maupun tertulis, termasuk yang saat ini berkembang adalah bahasa politik. Tidak hanya secara retorik tetapi juga paralinguistik seperti bahasa tubuh dan tindakan berpolitik semisal boikot dan protes. (Mc Nair, 1999: 4 ).

Berdasarkan pengertian di atas mengenai komunikasi politik, maka aspek yang diperhatikan adalah komunikasi politik yang dilakukan oleh seorang anggota legislatif perempuan baik secara verbal amupun non verbal, semua yang tindakan anggota legislatif perempuan itu adalah komunikasi politik yang dilakukannya. Karena politik seperti halnya komunikasi, bahwa siapa memperoleh apa, kapan dan dimana.
Komunikasi politik sebagai salah satu fungsi politik dalam sistem politik, dan bahkan komunikasi politik merupakan prasyarat yang diperlukan bagi berlangsungnya fungsi-fungsi lainnya (artikulasi, agresi, sosialisasi dan rekruitmen politik). (Arifin, 2011: 16)

Komunikasi politik berkaitan dengan sistem politik. Dimana dalam sistem terdapat beberapa subsitem yang saling terkait dan masing-masing memilikki fungsi tertentu, yang dikenal dengan sebutan struktur politik yang terdiri atas aspek infrastruktur politik dan aspek suprastruktur politik. Seperti yang ditulis oleh (Sumarno, 1989 :16) bahwa unsur-unsur yang ada dalam komunikasi politik terdapat dalam dua struktur, yaitu :

1. Unsur-unsur pada

suprastruktur politik Yaitu unsur yang berada dalam lembaga legislatif, eksekutif, yudikatif yang terdiri dari : elit politik, elit militer, teknokrat, profesional group.

2. Unsur-unsur pada infrastruktur politik

Unsur-unsur ini dibagi kedalam asosiasi-asosiasi atau kelompokkelompok, yaitu : partai politik, kelompok kepentingan, kelompok penekan, media komunikasi politik, pers, mahasiswa, tokoh politik.

Relasi komunikasi politik antara supra dan infrastruktur politik dengan gamblang bisa dipetakan ketika semua komponen yang bermuatan dengan komunikasi politik digambarkan. Realitas komunikasi politik sangat bergantung pada sistem komunikasi politik yang dalam dasaran tataran politiknya tidak selalu persis mencerminkan sistem politik itu sendiri. Peneliti ingin menyederhanakan kembali mengenai komunikasi politik yang dilakukan oleh anggota legislatif perempuan berkaitan dengan kebijakan penyusunan anggaran Badan 
Pemberdayaan

Masyarakat, Perempuandan KB di DPRD Kabupaten Majalengka. Proses komunikasi politik yang terjadi pada anggota legislatif perempuan meliputi komunikasi politik internal yang dilakukan oleh seorang anggota legislatif perempuan dalam kaitanya dengan kebijakan penyusunan anggaran adalah terdiri dari dua yaitu komunikasi internal dan komunikasi eksternal. Komunikasi internal adalah komunikasi yang terjadi di internal anggota legislatif perempuan, namun pada komunikasi internal ini terbagi menjadi dua bagian komunikasi dalam komisi dan komunikasi dalam komisi. Komunikasi di dalam komisi yang sama, namun terdiri dari komunikasi internal dan eksternal juga internal didalam diri sendiri dan transedental, sedangkan komunikasi eksternal komunikasi yang dilakukan dengan anggota legislatif yang lain di dalam satu komisi, yang tentunya ada yang bersifat horizontal dan vertikal. Sedangkan komunikasi dengan bagian luar anggota legislatif terdiri dari komunikasi dengan lembaga-lembaga atau instansi yang lain dan kedua dengan masyarakat. Komunikasi yang dilakukan dengan lembaga-lembaga atau dinas terdiri dari komunikasi dengan bagian eksekutif, DPRD Jabar, dinas, ada juga komunikasi dengan LSM dan Media. Sedangkan komunikasi dengan masyarakat terdiri dari komunikasi yang dilakukan dengan masyarakat umum, atau dengan daerah pilihan pada saat pemilihan itu.

\section{Metodologi Penelitian}

Pendekatan penelitian yang akan digunakan dalam penelitian ini adalah metode studi kasus yang dikembangkan dalam tradisi kualitatif. Studi kasus adalah sebuah metode/ pendekatan penelitian dengan cara mengkaji lebih dalam kasus tersebut.
Penelitian studi kasus yang digunakan oleh peneliti adalah penelitian studi kasus tunggal holistik. Penelitian studi kasus tunggal holistik (holistic singlecase study) adalah penelitian yang menempatkan sebuah kasus sebagai fokus dari penelitian. Kasus dipilih karena bersifat longitudinal, yaitu terjadi dalam dua atau lebih pada waktu yang berlainan. Kasus yang demikian sangat tepat untuk penelitian yang dimaksudkan untuk membuktikan terjadinya perubahan pada suatu kasus akibat berjalannya waktu. (Yin,2009: 46)

Seperti yang dipaparkan diatas maka penelitian ini oleh peneliti di golongkan pada penelitian studi kasus tunggal holistik, karena pada penelitian ini hanya meneliti satu kasus yang memiliki keunikan dalam kebijakan penyusunan anggaran di DPRD Kabupaten Majalengka, dimana pada kebijakan penyusunan tersebut, masing- masing membawa kepentingan tersendiri,sehingga kemungkinan terjadi adanya perubahan pada keputusan setiap anggota legislatif yang terlibat dalam kebiijakan penyusunan anggaran.

\section{Hasil dan Pembahasan}

\section{Persiapan dan perumusan strategi komunikasi politik anggota legislatif perempuan}

Pembahasan penyusunan anggaran itu akan disesuaikan dengan program RPJD dan KUA, sebagai tolak ukur pencapaian suatu program, dalam menentukan biaya yang harus dikeluarkan untuk sebuah program dan lokasi program itu diselenggarakan. Hal- hal ini yang harus dipertimbangkan dengan matang oleh anggota legislatif. Pada proses inilah biasanya terjadi yang namanya politik anggaran, setiap orang yang terkait dengan pembahasan dan 
penentuan kebijakan ini saling membawa kepentingan. Biasanya terjadi penyumbatan dan pemandulan aspirasi maupun kepentingan publik disebabkan oleh politik anggaran yang cenderung self and group oriented atau narrow self interest oleh para anggota legislatif. Politik anggaran yang pro rakyatkah ataukah politik anggaran yang lebih mengutamakan kepentingan kelompok. Setiap anggota legislatif sudah membawa pada saat rapat komisi dimulai.

Dimulai rencana kerja anggaran (RKA) yang diserahkan pada 4 bulan ditahun terakhir oleh eksekutif kepada legislatif, untuk dibahas lebih detail tentunya hal-hal yang berkaitan dengan program-program dengan spesifikasi kegiatan yang mendukung kesejahteraan rakyat. Sehingga yang menjadi pertimbangan anggota legislatif dari setiap program yang ada didalam rencana kerja anggaran adalah, tempat, waktu, dan siapa yang merasakan manfaat dari kegiatan tersebut, hal ini biasanya yang lebih dipertimbangkan untuk menetapkan kebijakan dalam penyusunan anggaran.

Perumusan dan persiapan strategi yang dilakukan oleh anggota legislatif perempuan adalah dengan cara mengumpulkan dulu semua aspirasi rakyat, semua informasi dari masyarakat yang menjadi permasalahan dan harapan- harapan masyarakat untuk tahun berikutnya. Perumusan dan persiapan strategi ini dilakukan oleh anggota legislatif perempuan bersama dengan anggota legislatif yang lain. Selain itu, partai ikut berperan serta dalam perumusan dan persiapaan strategi ini. Beberapa langkah-langkah yang dilakukan oleh anggota legislatif perempuan diantaranya adalah:

\section{Reses}

Permulaan dari perencanaan dan persiapan yang dilakukan oleh anggota legislatif sebelum kebijakan penyusunan anggaran adalah dengan mengadakan reses terlebih dahulu. Reses sebagai salah satu media yang dapat membantu anggota legislatif perempuan dalam mengumpulkan datadata masyarakat mengenai semua permasalahannya serta aspirasinya untuk masa yang akan datang. Reses atau masa reses adalah masa dimana DPR melakukan kegiatan di luar masa sidang, terutama di luar gedung DPR. Misalnya melakukan kunjungan kerja, baik yang dilakukan anggota secara perseorangan maupun secara berkelompok.

Kegiatan reses dilakukan karena dalam penetapan kebijakan penyusunan anggaran ini, mereka harus mengacu pada elemen-elemen yang berkaitan dengan kesejahteraan masyarakat, karena itu diharapkan dengan reses ini anggota wakil raykat mengetahui hal-hal yang dirasakan dan diusulkan oleh masyarakat setempat. Usulan-usualan masyarakat tersebut sangat berguna, dan menjadi sesuatu hal yang baru bagi anggota legislatif yang akhirnya akan dijadikan acuan dalam proses kebijakan penyusunan tersebut. eses dilakukan sekitar 4-6 jam, biasanya dimulai dengan pemaparan rencana kerja yang akan dilakukan dalam bentuk dialog mengenai program kerja yang telah dilakukan oleh para badan eksekutif berkaitan dengan kesejahteraan rakyat tentunya dengan warga masyarakat daerah pilihannya.

"Martin Buber (1970) dalam

buku ilmu komunikasi (Mulyana,Arifin,Cangara, 2011:323) : Memandang dialog sebagai inti komunikasi, dialog merupakan hubungan Saya-Anda (i-Thou), yaitu manusia dengan manusia, yang ditandai kebersamaan, keterukaan hati, kelangsungan, kejujuran, spontanitas, keterusterangan, tidak pura-pura, tidak manipulatif, kerukunan, intensitas, dan 
cinta kasih dalam arti bertanggung jawab kepada orang lain."

\section{Rapat fraksi}

Rapat fraksi sering dilakukan oleh anggota legislatif jika ada hal-hal yang menuntut untuk melakukan rapat ini, rapat fraksi dilakukan tidak tentu perberapa kali perbulannya. Tetapi jika berkaitan dengan agenda di DPRD yang tentunya harus dibahas oleh fraksi terlebih dahulu, maka rapat ini akan dilakukan. Namun jika berkaitan dengan kebijakan penyusunan anggaran, maka rapat fraksi biasanya dilakukan juga setelah reses dilakukan dan sebelum pembahasan kebijakan penyusunan anggaran yang diajukan eksekutif dalam bentuk rencana kerja anggaran (RKA) disetiap komisi oleh anggota legislatif. Perhelatan jarang terjadi ketika rapat fraksi karena hanya membahas program- program yang sudah berjalan sertaoleh bagian dari wakil-wakil komisi yang ada. Karena itu, rapat fraksi akan dilakukan setelah masa reses berakhir, hal ini dilakukan untuk membuat strategi baru dalam pembahasan RKA (rencana kerja anggrana) didalam komisi D yang berasal dari eksekutif kepada setiap komisinya, untuk ditetapkan kebijakan dalam penyusunan anggarannya. Komunikasi politik berperan dalam aktivitas partai politik yang pada umumnya adalah; pemikiran politik, pembicaraan politik, dan tindakan politik. Sedangkan partai politik menjadi jembatan arus informasi timbal balik dari"mereka yang memerintah" dengan mereka yang diperintah".

$$
\text { Fungsi partai sebagai }
$$

jembatan bagi rakyat dan wakil rakyat sangat berperan, sehingga sebelum diadakannya agenda dalam DPRD biasanya akan dilakukan rapat fraksi, atau apabila ada hal-hal yang tidak sesuai maka biasanya rapat fraksi segera dilakukan. Dalam hal menjembatani aspirasi rakyat maka, aspirasi rakyat biasanya berupa tuntutan dan kepentingan yang beragam yang disampaikan dalam berbagai cara, ditampung oleh partai politik, kemudian di olah dan dirumuskan sehingga bisa diteruskan kepada pemerintah dan pembuat kebijakan publik lainnya, dalam bentuk tuntutan atau usul kebijakan umum.

Semua hasil reses itu dikumpulkan dari setiap anggota legislatif didalam fraksi, untuk menjadi bahan kajian pada tiap divisi yang ada di fraksi lalu dikaji dan menjadi salah satu usulan yang di bawa oleh perwakilan komisi. Tidak semua anggota legislatif perempuan selalu mendahulukan kepentingan untuk perempuan saja, hanya beberapa orang, bahkan jika dilihat dari 6 orang hanya 3 orang yang sangat memperhatikan kepetingan perempuan, baik pada saat rapat fraksi maupun rapat komisi.

Peran dan keharusan keterlibatan perempuan diatur pada Pasal 27 UUD Tahun 1945 yang menyatakan "segala warga Negara bersamaan kedudukannya di dalam hukum dan pemerintahan dan wajib menjunjung hukum dan pemerintahan ini dengan tidak ada kecualinya". Hal ini menegaskan tidak adanya perbedaan hak antara laki-laki dan perempuan untuk berpartisipasi dalam pembangunan dan turun terlibat dalam mempengaruhi keputusan- keputusan politik. (Aida, 2010;496). Peran perempuan sangat diharapan di setiap keputusan didalam parlemen, karena itu affirmative action itu dilakukan. Baik dalam kegiatan parlemen atau partai, peran perempuan sebagai anggota legislatif seharusnya dapat memberi perubahan yang signifikan. Usulanusulan mengenai programadanya program-program yang berkaitan dengan pemberdayaan perempuan 
mulai mewarnai parlemen, ataupun aksi-aksi yang dilakukan anggota legislatif perempuan dalam hal kepedulian terhadap permasalahanpermasalahan yang berkaitan dengan perempuan.

Komunikasi politik yang digunakan oleh seorang anggota legislatif perempuan hampir semuanya lebih cenderung menjadi pendengar yang baik, dibandingkan memprovokatori atau mengadvokasi yang lainnya. Kebanyakan malah yang teradvokasi oleh yang lainnya, yaitu anggota legislatif laki-laki.

\section{Mengidentifikasi mensegmentasi sasaran}

Berdasarkan hasil penelitian hanya beberapa anggota legislatif yang menyadari bahwa setiap orang pada umumnya berbeda, apalagi kaitannya dengan parlemen setiap individu membawa kepentingan tertentu yang tanpa disadari dapat mencelakakan keberadaan anggota legislatif itu sendiri. Dari ke enam anggota legislatif perempuan hanya 2 orang yang melakukan segmentasi dan mengidentifikasikan khalayak. Dengan mengindentifikasikan khalayak maka akan dengan mudah melakukan komunikasi politik yang efektif. Segmentasi khalayak dilakukan berdasarkan kebutuhan, keinginan serta kepentingan dari suatu individu. Siapapun bisa menjadi khalayak, penerima (receiver), atau khalayak (audience), atau komunikan adalah pihak yang menjadi tujuan disampaikannya sesuatu pesan. Meskipun demikian khalayak sebenarnya hanyalah suatu peran yang sementara sifatnya. Sebab ketika pada giliran berikutnya penerima pesan akan memprakarsai penyampaian suatu pesanberikutnya, maka pada saat itu sebenarnya pihak yang tadinya disebut sebagai khalayak itu telah berubah peran menjadi komunikator.

\section{Mengemas serta mendesain isi pesan secara efektif}

Dari hasil reseslah kita mendapatkan informasi-informasi. Aspirasi-aspirasi dari warga masyarakat yang tentunya akan membantu anggota DPRD dalam menentukan isu yang mendesak, yang harus diselesaikan dengan cepat, dan juga mana isu yang membutuhkan proses yang cukup lama dalam penanganannya. Isu-isu tersebut dapat dikomunikasikan kepada partai bahkan kepada media untuk mampu membuat pencitraan yang baik bagi anggota DPRD tersebut. Persoalan untuk mengemas pesan politik dalam komunikasi politik menjadi urusan yang sangat penting bagi anggota legislatif perempuan agar makna pesan dapat diterima secara efektif oleh yang menerimanya. Tidak hanya dari reses dari berita-berita yang ditampilkan media massa, bisa dijadikan acuan untuk mendapatkan informasi-informasi mengenai kesejahteraan rakyat Kabupatenupaten. Majalengka. Biasanya jika ada berita yang memang harus segera ditangani oleh anggota legislatif, maka secepat mungkin anggota legislative ini akan terjun langsung dalam menyelesaikan segala permasalahan rakyat.

Namun, pesan yang disampaikan

oleh anggota legislatif perempuan memiliki nilai tersendiri bagi rekanrekan sesama anggota legislatif, maupun bagian eksekutif ataupun masyarakat. Desain pesan pada penelitian ini meliputi isu-isu politik yang berkaitan dengan kebijakan penyusunan anggaran badan pemberdayaan masyarakat, perempuan dan keluarga yang disampaikan oleh anggota legislatif perempuan. Isu-isu politik itu tentunya akan dijadikan acuan dalam kebijakan penyusunan anggaran tersebut, tentunya didapatkan 
dari komunikasi yang dilakukan antara anggota legislatif dengan masyarakat, dan fraksinya.

Dalam merancang strategi dapat memberikan masukan-masukan yang berkaitan dengan isu-isu perempuan di lingkungan Kabupaten Majalengka, dalam hal penetapan kebijakan penyusunan anggaran badan pemberdayaan perempuan, maka untuk memberikan usulan-usulan atau masukan-masukan pada programprogram tersebut, seorang anggota legislatif, tidak sebatas hanya menjawab "setuju" atau "tidak setuju" saja terhadap program-program yang ada yang berkaitan dengan penyusunan anggaran, namun harus dilandasi oleh alasan-alasanyang kuat dan mendukung pada saat memberikan keputusan.

Dalam pembahasan kebijakan penyusunan anggaran maka pengemasan pesan biasanya dilakukan oleh partai juga. Sebelum pembahasan rencana kerja anggaran maka anggota legislatif akan melakukan rapat fraksi, dimana akan dilakukannya pembahasan-pembahasan mengenai pesan apa saja ingin disampaikan serta strategi pengemasan pesan yang dilakukan disetiap komisi. Sehingga diharapkan setiap anggota legislatif mampu mengungkapkan argumenargumennya pada saat rapat komisi dalam pembahasan rencana kerja anggaran yang merupakan salah satu proses kebijakan penyusunan anggaran.

\section{Mengemas serta mendesain isi pesan secara efektif}

Pesan adalah apa yang mendorong kebijakan penyusunan anggaran badan pemberdayaan perempuan dan KB, dengan menetapkan parameter dalam strategi yang dibuat. Karena itu tahapan awal dalam mendesain pesan, yang dilakukan para anggota legislatif perempuan terlebih dahulu melakukan jajak pendapat dengan menggunakan reses. Aspirasi- aspirasi dari warga masyarakat yang tentunya akan membantu anggota DPRD dalam menentukan isu yang mendesak, yang harus diselesaikan dengan cepat, dan juga mana isu yang membutuhkan proses yang cukup lama dalam penanganannya. Isu-isu tersebut dapat dikomunikasikan kepada partai bahkan kepada media untuk mampu membuat pencitraan yang baik bagi anggota DPRD tersebut. Persoalan untuk mengemas pesan politik dalam komunikasi politik menjadi urusan yang sangat penting bagi anggota legislatif perempuan agar makna pesan dapat diterima secara efektif oleh yang menerimanya. Tidak hanya dari reses dari berita-berita yang ditampilkan media massa, bisa dijadikan acuan untuk mendapatkan informasiinformasi mengenai kesejahteraan rakyat Kabupaten Majalengka. Biasanya jika ada berita yang memang harus segera ditangani oleh anggota legislatif, maka secepat mungkin anggota legislatif ini akan terjun langsung dalam menyelesaikan segala permasalahan rakyat.

Namun, pesan yang disampaikan oleh anggota legislatif perempuan memiliki nilai tersendiri bagi rekanrekan sesama anggota legislatif, maupun bagian eksekutif ataupun masyarakat. Desain pesan pada penelitian ini meliputi isu-isu politik yang berkaitan dengankebijakan penyusunan anggaran badan pemberdayaan masyarakat, perempuan dan keluarga yang disampaikan oleh anggota legislatif perempuan. Isu-isu politik itu tentunya akan dijadikan acuan dalam kebijakan penyusunan anggaran tersebut, tentunya didapatkan dari komunikasi yang dilakukan antara anggota legislatif dengan masyarakat, 
dan fraksinya. Tehnik pesan yang dilakukan oleh anggota legislatif adalah berupa tehnik negosiasi atau lobi, karena dengan tehnik pesan yang seperti itu kita akan mampu bernegosiasii lawan bicara kita baik didalam komisi maupun di non komisi, baik dengan sesama anggota legislatif maupun dengan bagian eksekutif, yang tentunya setiap orang berdasarkan memiliki kepentingan baik kepentingan pribadi, partai maupun kepentingan komisi.

Negosiasi politik bertujuan mencapai pengertian bersama diantara pihak-pihak tentang apa makna syaratsyarat persetujuan yang iterima. Mereka berharap menciptakan pengharapan bersama mengenai bagaimana pihak-pihak akan bertindak terhadap satu sama lain dimasa mendatang. Negosiasi mempengaruhi pengarapan masing- masing. (Dan nimmo, 2005: 75).

Tehnik negosiasi akan dilakukan jika anggota legislatif memberikan pendapat-pendapatnya mengenai rencana kerja anggaran sebagai salah satu proses kebijakan penyusunan anggraan pada badan pemberdayaan masyarakat, perempaun dan $\mathrm{KB}$, baik pada saat berkomunikasi dengan sesama anggota elgislatif maupun dengan pihak-pihak luar (eksekutif, media, partai, dsb). Sehingga ketika akan emlakukan pengemasan pesan maka yang harus diperhatikan adalah siapa khalayak atau orang yang akan menerima tersebut. Dalam pengemasan dan pendesaianan isi pesan ini dipengaruhi oleh jenis khalayak yang akan dihadapi oleh anggota legislatif sehingga dalam pengemasan pesannya disesuaikan dengan jenis khalayaknya. Pembicaraan politik apapun harus dilihat terlebih dahulu pihak-pihak yang akan terkait dengan pesan yang akan disampaikan, dan setiap orang atau lembaga itu berbeda, baik berbeda secara pendidikan, pengalaman.

Karena pembicaraan politik dilakukan sebagai kegiatan orang- orang yang mengatur perbuatan mereka dalam kondisi konflik sosial, yakni usaha untuk merundingkan penyelesaian yang dapat diterima.Jika politik cukup menjangkau setiap kegiatan yang mengatur perbuatan manusia sehingga menjamin kelanjutan kegiatan lain itu, yakni kegiatan nonpolitik dan karena itu pembicaraan politik adalah pembicaraan yang memelihara pembicaraan lain). Dalam arti luas, "kata-kata" politik menjangkau melewati ungkapan yang dikatakan atau dituliskan kepada gambat, lukisan, foto, film (kata orang, gambar sama nilainya dengan seribu kata), kepada gerak tubuh, ekspresi wajah, dan segala cara bertindak (menurut peribahasa, tindakan berbicara lebih nyaring daripada katakata), jenis kata-kata politik yang lain adalah lambang. Dalam pembicaraan politik jika lambang adalah kata-kata dari pembicaraan politik maka bahasa adalah permainan kata dari wacana.

Dalam hal mengemukakan pendapat yang berkaitan dengan rencana kerja anggaran maka sebaiknya lebih di fokuskan pada pesan verbal, dimana anggota legisatif dapat memberikan pandangan-pandangan secara persuasif dengan memperhatikan isi pesan dan struktur pesan yang akan disampaikan.

Syarat-syarat yang perlu diperhatikan dalam menyusun pesan politik yang bersifat persuasif adalah menentukan tema dan materi yang sesuai dengan kondisi dan situasi khalayak. Syarat utama dalam mempengaruhi khalayak dari pesan tersebut ialah harus mampu membangkitkan perhatian, sehingga upaya pertama yang dapat dlakukan dalam penyusun pesan persuasif ialah bangkitnya perhatian dari khalayak 
terhadap pesan-pesan politik yang disampaikan. (Arifin, 2011:248)

Pengemasan pesan secara persuasif harus dengan penyampaian secara retorika. Setiap bahasa mempunyai peraturan bagaimana katakata harus disusun dan dirangkaikan supaya memberikan makna. Pesan yang disampaikan akan berkaitan dengan opini yang akan tercipta pada komunikanya. Pengemasan pesan akan dapat mempengaruhi media apa yang akan digunakan oleh anggota legislatif berkaitan dengan pesan yang ingin disampaikannya.

\section{Penggunaan Media Secara Efektif}

Media yang digunakan oleh anggota DPRD dalam hal ini adalah sebagai alat penyampaian pesan yang disampaikan oleh DPRD sebagai wakil rakyat kepada masyarakat, serta kepada beberapa lembaga terkait, dengan berbagai feedback yang di harapkan berkaitan dengan kebijkaan penyusunan anggaran Badan Pemberdayaan Masyarakat, Perempuan dan Keluarga Berencana. media yang digunakan adalah media massa, dan media personal. Media massa yang sering digunakan oleh anggota DPRD kabupaten majalengka adalah media cetak. Pada media cetak ini, anggota DPRD selalu memberikan informasi atau pandangannya, ataupun dapat mengetahui informasi seputar lingkungan Majalengka yang berkaitan dengan kesejahteraan masyarakat Majalengka. Bagi DPRD perempuan penggunaan media merupakan salah satu alat yang digunakan dalam membantu kiprahnya di legislatif. Media lokal lebih intens dalam mewarnai pergerakan politik anggota DPRD di Kabupaten Majalengka, seperti radar majalengka, majalengka news, sinar media, radar cirebon. Hampir setiap hari media lokal tersebut bergelut di gedung DPRD mengamati tingkah polah para anggota DPRD Kabupaten Majalengka. Para anggota DPRD perempuan jarang menggunakan media massa dalam sepakterjangnya di dunia politik, mereka lebih mengikuti alur nyaman yang sudah ada, seolaholah tidak mau terlibat konflik. Jadi dalam hal penetapan kebijakan terhadap program-program yang berkiatan dengan pemberdayaan perempuan pun media tidak sepenuhnya berinisiatif dalam menggunakan media, terkecuali jika ada informasi/ berita yang dikaji media berkaitan dengan program pemberdayaan perempuan barulah mucul peranan anggota legislatif perempuan.

Kesamaan utama antara politik dan media ada pada hubungannya dengan orang banyak. Kedua ranah tersebut membutuhkan dan dibutuhkan oleh masyarakat, yang anonim, dalam melakukan operasioperasi rutinnya. Politik berurusan dengan ideologi, dan topik ideologi tentu saja menyangkut kehidupan sosial rakyat. Sementara media adalah jembatan atau tema yang akan diangkat dengan rakyat yang tersebar. Setiap media memiliki kepentingan tersendiri sehingga tidak setiap anggota legislatif bebas dalam berpendapat, harus tetap hati-hati dan menjaga pencitraan. Menjaga pencitraan sangat penting dan sering dilakukan oleh para elit politik, hal ini dilakukan dalam menjaga citra dirinya, partai dan lembaga parlemen itu sendiri.

Keadaan itu sungguh dilematis, secara teoritis, keduanya harusnya bisa berjalan dengan harmoni. Media massa bisa memediasi kegiatan politik dari para politisi kepada masyarakat. Dan sebaliknya, media juga bisa memediasi opini, tuntutan, atau reaksi masyarakat kepada para politisi. Karena media massa adalah ruang lalu lintas bagi 
segala macam ide-ide yang menyangkut kepentingan orang banyak. Jika dilihat pada fungsi media yakni, memberikaninformasi, memberikan pendidikan, memberikan hiburan, dan melakukan kontrol sosial.

\section{Strategi komunikasi yang dilakukan anggota legislatif perempuan sebagai komunikator politik}

Alam perspektif panggung politik, komunikator politik memainkan peran sosial yang utama, khususnya dalam proses pembentukan opini publik. Opini publik dipahami sebagai sejenis tanggapan publik terhadap pemikiran dan usaha para aristokrat pikiran itu yang menciptakan pemikiran-pemikiran baru, gagasangagasan baru, argumen-argumen baru. (Dan Nimmo, 2005:29).

Sehingga komunikator politik sebagai pelaku atau di identifikasi sebagai pemimpin yang memiliki potensi dan kompetensi di atas rata-rata dibandingkan warga negara pada umumnya dalam hal menyampaikan pikiran atau gagasan di mana pun dia berada. Upaya untuk menyatakan dirinya sebagai komunikator politik, meliputi; politisi, komunikator profesional, dan aktivis (Dan Nimmo, 2005:37) maka yang dituntut adalah; Pertama, kemampuan berkomunikasi. Kemampuan berkomunikasi mempunyai makna bahwa seorang yang mampu dan cerdas dalam menyampaikan argumen, gagasan, dan pemikiran kepada publik, di mana pun dia berada. Artinya, di mana pun dia berada setiap statement mampu mempengaruhi atau bergetar dalam setiap apa yang diucapkan. Misalnya, sebagai politisi, diharapkan dalam melontarkan gagasan mampu mempengaruhi kebijakan politik berkaitan dengan pemberdayaan perempuan.
Apabila politisi yang sehari-hari bekerja di lembaga legislatif mampu memainkan perannya sebagai aktivis politik, baik itu menjalankan fungsi kontrol, legislasi, dan anggaran. Ukurannya, seberapa besar media massa memberikan porsi pemberitaan dalam apresiasinya dalam menjalankan tugasnya sebagai komunikator politik. Kalau mereka sebagai politisi tidak pernah kita ketahui kiprahnya, dan hanya anggota dewan semata dan sosoknya hanya $4 \mathrm{D}$ (datang, duduk, dengar, diam) itu berarti mereka tidak dapat dikatakan sebagai komunikator politik yang baik. Kedua, komunikator politik sebaiknya memiliki kesempatan dan memiliki kapasitas sebagai pemimpin.

Orang yang mengidentifikasi dirinya berkemampuan sebagai komunikator politik adalah orang yang memiliki leadership. Bagi orang yang menceburkan diri dalam panggung politik dan kekuasaan, hal yang tidak bisa ditawarkan adalah memiliki kemampuan dalam memimpin. Pemimpin itu tidak lahir seketika atau instant. Pemimpin sejak lahir sudah terlihat bakatnya sebagai pemimpin di mana pun dia berada. Untuk DPRD saja, yang cakupannya hanya kabupaten, setiap anggota legislatif yang tentunya pada saat menjerumuskan dirinya di legislatif seharunya memiliki kapasitas dan kapabilitas yang tinggi sebagai komunikator politik, karena walaupun mereka memang sebagai wakil rakyat, mereka juga adalah sebagai patner dari badan eksekutif yang tentunya orang- orang di eksekutif ini memiliki kapasitas dan kapabilitas yang tinggi baik secara keilmuan ataupun keahlian karena pengalamannya yang sudah banyak bergelut dibidangnya. Sementara anggota legislatif khusunya legislatif perempuan baru memiliki pengalaman di periode ini, bagaimana bisa 
menjadi aktor komunikasi politik yang baik ketika berhadapan dengan eksekutif. Dilihat dari segi pendidikan jauh lebih tinggi bagian eksekutif biasanya dalam hal ini kepala Dinas pendidikannya sudah S2, sementara jika dibandingkan dengan pengalaman juga, tentunya untuk menjadi seorang kepala dinas, kiprahnya dieksekutif harus sudah memiliki pengalaman yang bertahun-tahun. Jika para politisi tersebut masih memiliki syarat utama yang harus dimiliki sebagai komunikator politik, publik tidak akan mempersoalkan. Apapun alasannya, kalau seandainya, politisi tersebut yang sementara dipersoalkan di publik tidak memiliki syarat utama sebagai komunikator, secara tataran akademik maupun tuntutan public sepantasnya caleg tersebut perlu bercermin dan menanyakan dirinya sendiri.

\section{Daftar Pustaka}

Arifin, Anwar.2011. Komunikasi politik.Yogyakarta: Graha Ilmu

Aida. 2010. Pemberdayaan perempuan dari masa ke masa.Bogor: PT. Penerbit IPB Press

Ayu, R. K. 2017. Perempuan Pebisnis Startup di Indonesia dalam Perspektif Cybertopia. Jurnal Studi Komunikasi, 1(2).

Budiardjo, Miriam. 1982. Dasar-dasar ilmu politik.Jakarta: PT.Gramedia

Creswell, John W. 1998. Qualitative Inquiry and Research Design Choosing Among Five Approaches. California: Sage Publications, Inc.

Devito, Josep. 1997. Komunikasi antar manusia.Jakarta: Professional book.

Dan Nimmo, 2005. Komunikasi politik: komunikator, pesan, dan media. Bandung: PT. Remaja Rosdakarya.

Dan Nimmo, 2010. Komunikasi politik: khalayak dan efek. Bandung: PT. Remaja Rosdakarya.
Effendi, Onong. 1998. Ilmu, Teori, dan Filsafat Komunikasi. Bandung: PT. Remaja Rosdakarya.

Effendi, Onong. 1993. Ilmu Komunikasi, Teori dan Praktek. Bandung: Remaja Rosda Karya.

Effendi, Onong. 2000.Ilmu Komunikasi.Bandung : Remaja Rosdakarya.

F. Ivan Nye. 1976. Role Structure and Analysis of the Family. California \& London: Sage Library of Social Research.

Liliweri, Alo, 1998. Komunikasi verbal dan non verbal. PT. Citra Aditya Bakti: Jakarta

McNair, Brian. 2003. An Introduction to Political Communication ed. $3^{\text {rd }}$. London: Routledge.

Megawangi, Ratna. 1999. Membiarkan berbeda:Sudut Pandang Baru Tentang Relasi Gender.Bandung:Mizan

Miles, MB \& Huberman, AM. 1984. Qualitative Data Analysis : A Sourcebook of New Methods. California : Sage Publications, Inc

Moleong, Lexy J. 2004. Metode Penelitian Kualitatif. Bandung : PT. Remaja Rosdakarya.

Mulyana, Deddy. 2001. Metodologi Penelitian Kualitatif. Bandung: PT. Remaja Rosdakarya. 2007. Ilmu Komunikasi Suatu Pengantar.Bandung Remaja Rosdakarya

Nasution, Zulkarimein. 1990. Komunikasi Politik Suatu Pengantar. Jakarta: Yudhistira.

Nasrudin.1999.Argumen Kesetaraan Gender:Perspektif AlQur'an.Jakarta: Paramadina Nimmo, Dan. 1989. Komunikasi Politik: Khalayak dan Efek. Terjemahan Tjun Surjaman. Bandung: PT. Remaja Rosdakarya. 2003. Komunikasi Politik: Komunikator, Pesan dan Media. 
Terjemahan Tjun Surjaman. Bandung: PT. Remaja Rosdakarya.

Panuju, Redi. 1997. Sistem Komunikasi Indonesia. Pustaka Pelajar: Yogyakarta

Pawito. 2007. Penelitian Komunikasi Kualitatif. Yogyakarta: PT. LKis Pelangi Aksara Rosdakarya

Rakhmat, Jalaluddin. 2001. Psikologi Komunikasi. Bandung : PT. Remaja

Sumarno. 1989. Dimensi-dimensi komunikasi politik. Bandung: PT Citra Aditya Bakti.

Sulistyowati, I.\& Kartika. 2009. Panduan tentang gender di parlemen. Jakarta:Sekretariat Jendral DPR RI\&UNDP

Susilo, Daniel, Perempuan dan Korupsi: Wacana Media Dalam Berita Tindak Pidana Korupsi Perempuan (Women and Corruption: Media Discourse on News Reporting about Women's Corruptor) (September 23, 2016). Konferensi Internasional Feminisme: Persilangan Identitas, Agensi dan Politik (20Tahun Jurnal Perempuan). 2016. Yayasan Jurnal Perempuan, 23-24 September 2016. Available at SSRN: https://ssrn.com/abstract $=2907291$

Sylvia,W. 1998. Theorizing patriarchy. Oxford:Blackwel.

Yin, Robert K. 2006. Studi Kasus Desain dan Metode. Jakarta: Raja Grafindo Persada

Wasistiono. 2009. Meningkatkan Kinerja Anggota legislatif perwakilan Rakyat (DPRD).Bandung:Pokusmedia Sumber lain:

Rina.2009.pemilihan umum anggota dewan. Melalui http://id.wikipedia.org/wiki/Pemilih an Umu m Anggota DPR, DPD, dan DPR D Indonesia 2004), diakses 03 september 2011 www.kppjabar.org, diakses pada 2 September 2011
Taufik,ivan. 2010. Kabupaten Majalengka. Melalui www. Majalengka.co.id(diakses pada tanggal 3 September 2011)

M.Zainuri. 2010. Tesis. Partisipasi politik perempuan(perspektif tradisi islam lokal kudus). Yogyakarta: UIN

Dwi Windyastuti Budi Hendrarti. 2009. Perempuan dalam pemilukada kajian tentang kandidasi perempuan di Jawa Timur dan Sulawesi Utara. Semarang: UNDIP

Yasinta Ayu Sekarini.Strategi komunikasi politik anggtota legislatif perempuan DPRD Kota Baru periode 2009-2014. Purwokerto: UNSOED

Darmawan, Ridwan Achmad. 2011. Kaukus perempuan parlemen. Melalui 